\title{
ANALISIS PEMINDAHAN DEPO KERETA GUNA MENGURANGI KELAMBATAN PERKA
}

\author{
Julison Arifin', Aditya Lesamana ${ }^{2}$, Utut widyanto ${ }^{3}$ \\ 1), 2), ${ }^{3)}$ PTDI-STTD \\ Email: j.arifin@yahoo.com
}

\begin{abstract}
Increasing the length of the main cross on DAOP 7 Madiun result Train Layout Parent Depo become less strategic. Caused by a distance that is too far away and it takes quite a long time in the distribution of the train that used as a series of departures Railway Station originally from Kediri. Lack of facilities and equipment maintenance in PUS Kediri so the train had to be treated in Depo Parent Madiun. Empty train journey from Kediri to Madiun very disturbing rail operations on highway traffic because DAOP 7 Madiun still using a single-track system. To solve these problems the method that used is to identify the needs of the facility on the basis of MI (Maintenance Instruction) as a guideline in conducting maintenance and calculate employee needs both in quantity or quality and competencies that should be owned care providers. From the analysis of the existing problems can be concluded that the completeness treatment care facilities and personnel of PUS Kediri still lacking. Therefore, there should be additional train maintenance facilities and improving the quality and quantity of human resources to improve the performance of treatment PUS Kediri.
\end{abstract}

Keywords: empty train travel, work equipment, personnel care, competence.

\section{ABSTRAK}

Bertambah panjangnya lintas utama pada DAOP 7 Madiun mengakibatkan Letak Depo Induk Kereta menjadi kurang strategis. Disebabkan oleh jarak yang terlalu jauh dan membutuhkan waktu yang cukup lama dalam pendistribusian kereta yang akan digunakan sebagai rangkaian Kereta Api yang keberangkatan awalnya dari Stasiun Kediri. Kurangnya fasilitas dan peralatan perawatan di PUS Kediri sehingga kereta harus dirawat di Depo Induk Madiun. Perjalanan kereta kosong dari Kediri menuju Madiun sangat mengganggu operasional kereta api pada lintas raya karena DAOP 7 Madiun masih menggunakan sistem jalur tunggal. Untuk mengatasi masalah tersebut metode yang digunakan adalah mengidentifikasi kebutuhan fasilitas dengan berdasarkan MI (Maintenance Instruction) sebagai pedoman dalam melakukan perawatan dan menghitung kebutuhan pegawai baik jumlah maupun kualitas atau kompetensi yang seharusnya dimiliki tenaga perawatan. Dari hasil analisis terhadap permasalahan yang ada dapat disimpulkan bahwa kelengakapn fasilitas perawatan dan tenaga perawtan PUS Kediri masih kurang. Oleh karena itu perlu diadakan penambahan fasilitas perawatan kereta dan peningkatan kualitas dan kuantitas sumber daya manusia untuk meningkatkan kinerja perawatan PUS Kediri.

Kata kunci: perjalanan kereta kosong, peralatan kerja, tenaga perawatan, kompetensi.

\section{PENDAHULUAN}

Kereta api merupakan salah satu moda yang bersifat massal. Keunggulan khusus Kereta Api dibandingkan dengan moda transportasi lainnya yakni hemat energi, ramah lingkungan, tidak memerlukan lahan yang besar untuk pembangunan jalan rel, serta mempunyai keamanan yang tinggi. Depo Induk Kereta DAOP 7 Madiun merupakan tempat untuk menyimpan, menyiapkan, melakukan pemeriksaan, pemeliharaan, dan perbaikan sarana kereta milik DAOP 7 Madiun.

Bertambahnya panjang lintas utama pada DAOP 7 Madiun mengakibatkan Letak Depo Induk Kereta menjadi kurang strategis. Disebabkan oleh jarak yang terlalu jauh dan membutuhkan waktu yang cukup lama dalam pendistribusian kereta yang akan digunakan sebagai rangkaian Kereta Api yang keberangkatan awalnya dari Stasiun Kediri. Perjalanan kereta kosong dari Kediri menuju Madiun sangat mengganggu operasional kereta api pada lintas raya karena DAOP 7 Madiun masih menggunakan sistem jalur tunggal.

DAOP 7 Madiun memiliki 3 Kereta Api jarak jauh yaitu, KA Krakatau, KA Brantas, dan KA Kahuripan. Ketiga kereta api tersebut mengawali keberangkatannya dari Stasiun Kediri, hal ini mengakibatkan peran dan letak Depo Kereta di Stasiun Kediri menjadi sangat penting. Kerusakan atau gangguan yang ditemukan dalam pemeriksaan harian (Daily Check) kereta tidak bisa di atasi segera oleh depo kereta, dikarenakan kurangnya peralatan yang dimiliki oleh Pusat Urusan Sarana 
(PUS) Kediri yang menjadi tempat awal keberangkatan kereta. Penggantian kereta yang rusak membutuhkan waktu yang cukup lama karena pihak terkait harus mengambil atau meminta kereta cadangan dari Depo Induk Kereta di Stasiun Madiun. Kondisi tersebut sangat mengganggu operasional Kereta Api di wilayah DAOP 7 Madiun terutama lintas raya Surabaya GubengYogyakarta. Proses pelepasan dan perangkaian kereta yang akan di rawat di Stasiun Madiun dapat berpotensi bahaya dan membuat kelambatan PERKA, hal ini disebabkan kereta tersebut harus langsir di lintas utama yang digunakan sebagai jalur kereta api cepat. Sedangkan untuk DAOP 7 Madiun masih berupa sistem jalur tunggal.

Melalui penjelasan di atas, maka peneliti ingin menganalisis pemindahan depo kereta agar dapat mengurangi kelambatan perka untuk memperlancar operasional kereta api di wilayah DAOP 7 Madian.

\section{KAJIAN LITERATUR Aspek Legalitas}

a) Undang-Undang Nomor 23 Tahun 2007 Tentang Perkeretaapian

Pada Undang-Undang Nomor 23 Tahun 2007 dijelaskan bahwa sarana kerata api harus dilakukan perawatan guna memenuhi standart kelaikan operasi. Sarana perkereta apian yang harus mekakukan perawatan yaitu Lokomotif, Kereta, Gerbong, dan Sarana Khusus. Perawatan sarana dilakukan di Depo atau balai yasa oleh tenaga yang memenuhi persyaratan dan kualifikasi keahlian di bidang sarana perkeretaapian.

b) Peraturan Pemerintah No. 56 Tahun 2009 Tentang Penyelenggara Perkeretaapian

Pada Peraturan Pemerintah No. 56 Tahun 2009 dijleaskan bahwa sarana kereta api dirawat sesuai dengan jadwal menggunakan peralatan yang memenuhi standar dan dilakukan oleh orang yang berkompetensi. Kualifikasi keahlian diberikan oleh diberikan oleh penyelenggaran pendidikan dan pelatihan tenaga pemeriksa atau tenaga perawatan sarana perkeretaapian yang diawasi oleh Menteri.

c) Peraturan Menteri No. 94 Tahun 2010 tentang Tenaga Perawatan Sarana Perkeretaapian

Pada Peraturan Menteri No. 94 Tahun 2010 dijalaskan bahwa perawatan harus dilakukan guna mempertahankan kehandalan agar sarana kereta api tetap laik operasi. Tenaga yang berkompetensi harus mengetahui dan memahami tata cara dan prosedur, mampu menganalisa dan mengevaluasi hasil perawatan, dan mampu menilai kelaikan operasi sarana perkeretaapian.

\section{Perawatan}

Pengertian perawatan menurut Harold T. Armine ("Reliability in Engineering Design", John Willey \& Sons, 1977) adalah suatu fungsi dari proses pabrikasi yang berhubungan dengan masalah penelitian fisik pabrik yang meliputi mesin-mesin produksi dan fasilitas-fasilitas penunjang produksi dari waktu ke waktu untuk dapat beroperasi dalam kondisi yang baik. Tujuan utama dari perawatan (maintenance) adalah mempertahankan keandalan dan kelaikan opersi serta ketersediaan sarana untuk menjamin kelancaran pelayanan angkutan kereta api. Jenis-jenis dari perawatan adalah sebagai berikut :

\section{a) Corrective Maintenance}

Perawatan perbaikan adalah perawatan yang dilakukan setelah terjadi kerusakan atau sistem tidak dapat berfungsi dengan baik. Tindakan yang dilakukan bertujuan untuk mengendalikan performansi kerja fasilitas/mesin pada kondisi yang dapat diterima (standar). Kegiatan perawatan ini juga sering disebut sebagai kegiatan reparasi yang biasanya terjadi karena perawatan pencegahan tidak dilakukan sama sekali atau perawatan pencegahan tetap dilakukan tetapi pada suatu waktu tertentu fasilitas tersebut tetap rusak.

b) Preventive Maintenance 
Perawatan pencegahan adalah kegiatan perawatan yang dilakukan untuk mencegah timbulnya kerusakan-kerusakan yang tidak dapat terduga dan menemukan kondisi dan keadaan yang dapat menyebabkan sistem mengalami kerusakan pada waktu dioperasikan. Dengan demikian, semua sarana yang mendapat perawatan pencegahan akan terjamin kelancaran operasinya dan selalu diusahakan dalam kondisi yang laik operasi. Perawatan jenis ini diterapkan pada komponen yang langsung mempengaruhi keandalan sarana.

c) Design Out Maintenance

Perawatan ini dilaksanakan dengan cara mendesain peralatan-peralatan yang dipergunakan secara sistematis, untuk memperoleh hasil perawatan yang lebih baik (dalam hal kualitas dan kuantitas).

d) Systematic Maintenance

Disebut juga periodic maintenance, yaitu perawatan yang dilakukan secara berkala. Untuk sarana perkeretaapian di PT KA, dikenal dengan pemeliharaan harian, bulanan, tiga bulanan, enam bulanan, satu tahunan, Semi Pemeriksaan Akhir (SPA), dan Pemeriksaan Akhir (PA).

e) Condition Based Maintenance

Adalah jenis dari preventive maintenance, dimana penggantian komponen dilakukan sesaat sebelum komponen tersebut rusak atau membahayakan. Condition based dilaksanakan dengan melakukan pengukuran-pengukuran.

Dalam melakukan pekerjaan perawatan ada beberapa unsur-unsur yang harus dipenuhi. Unsurunsur dalam manajemen perawatan kereta adalah sebagai berikut:

a) Pedoman

Pedoman merupakan petunjuk atau instruksi dari pabrikan (Maintenance Instruction) yang digunakan sebagai tata cara dan standar pelaksanaan perawatan mengenai bagaimana melakukan pekerjaan perawatan.

b) Fasilitas

Fasilitas merupakan peralatan dan tempat kerja yang digunakan untuk perawatan sarana.

c) Sumber Daya Manusia (SDM)

Sumber daya manusia merupakan orang yang melaksanankan pekerjaan perawatan, dibutuhkan dalam memenuhi pekerjaan perawatan baik dari kualitas maupun kuantitas.

d) Suku Cadang

Suku cadang merupakan bagian penting yang digunakan untuk mengganti komponenkomponen yang mengalami kerusakan atau harus diganti.

e) Biaya

Biaya merupakan suatu nilai yang harus dikeluarkan untuk menghasilkan sesuatu.

Dari kelima unsur-unsur tersebut jika sudah terpenuhi maka kegiatan perawatan bisa dilaksanakan dengan lancar sehingga akan menghasilkan ketersediaan dan kelaikan serta keandalan sarana. Ketersediaan merupakan hasil dari perawatan yang memenuhi sarana siap operasi. Sedangkan kelaikan dan keandalan sarana dapat diartikan sebagai sarana dapat beroperasi tanpa mengalami kerusakan dalam kondisi lingkungan saat dinasan.

\section{METODE}

Langkah awal dalam rencana penelitian ini adalah dengan melakukan pengumpulan data baik yang bersifat kuantitatif maupun kualitatif. Data tersebut terdiri dari data sekunder dan data primer yang digunakan sebagai petunjuk dan pedoman kinerja pelayanan Depo Induk Kereta Madiun. Penelitian akan dilaksanakan di DOAP 7 Madiun dengan pengumpulan data dan informasi berdasarkan buku-buku referensi maupun peraturan yang ada. 


\section{PEMBAHASAN}

\section{Sumber Daya Manusia}

a. Beban Kerja Pegawai

Jam kerja rata-rata per hari setiap pegawai adalah selama 6 jam sehari dan dalam satu minggu terdapat 6 hari kerja, tetapi dalam prakteknya sering terjadi penambahan jam kerja dikarenakan pekerjaan yang harus segera diselesaikan. Dalam sebulan pegawai rata-rata memiliki 26 hari kerja. Menurut data yang diperoleh dari Supervisor Administrasi Depo Kereta Madiun, dasar perhitungan di Depo Kereta Madiun adalah :

Tabel 1. Perhitungan Beban Kerja Pegawai (Bkp)

\begin{tabular}{|c|c|c|c|c|}
\hline \multicolumn{5}{|c|}{$\mathrm{K} 2$} \\
\hline $\begin{array}{c}\text { JENIS } \\
\text { PERAWATAN }\end{array}$ & ARMADA & FREK & JO & Bkp \\
\hline $\mathrm{P} 1$ & 2 & 8 & 15 & 240 \\
\hline P3 & 2 & 2 & 37 & 148 \\
\hline P6 & 2 & 1 & 49 & 98 \\
\hline P12 & 2 & 1 & 68 & 136 \\
\hline \multicolumn{4}{|c|}{ TOTAL } & 622 \\
\hline \multicolumn{5}{|c|}{$\mathrm{K} 3$} \\
\hline $\begin{array}{c}\text { JENIS } \\
\text { PERAWATAN }\end{array}$ & ARMADA & FREK & JO & Bkp \\
\hline $\mathrm{P} 1$ & 56 & 8 & 13 & 5824 \\
\hline P3 & 56 & 2 & 34 & 3808 \\
\hline P6 & 56 & 1 & 46 & 2576 \\
\hline P12 & 56 & 1 & 64 & 3584 \\
\hline \multicolumn{4}{|c|}{ TOTAL } & 15792 \\
\hline \multicolumn{5}{|c|}{ KMP3/MP3 } \\
\hline $\begin{array}{c}\text { JENIS } \\
\text { PERAWATAN } \\
\end{array}$ & ARMADA & FREK & $\mathrm{JO}$ & Bkp \\
\hline $\mathrm{P} 1$ & 8 & 8 & 19 & 1216 \\
\hline P3 & 8 & 2 & 46 & 736 \\
\hline $\mathrm{P} 6$ & 8 & 1 & 58 & 464 \\
\hline P12 & 8 & 1 & 83 & 664 \\
\hline \multicolumn{4}{|c|}{ TOTAL } & 3080 \\
\hline \multicolumn{5}{|c|}{$\mathrm{B}$} \\
\hline $\begin{array}{c}\text { JENIS } \\
\text { PERAWATAN }\end{array}$ & ARMADA & FREK & $\mathrm{JO}$ & Bkp \\
\hline $\mathrm{P} 1$ & 6 & 8 & 9 & 432 \\
\hline $\mathrm{P} 3$ & 6 & 2 & 28 & 336 \\
\hline P6 & 6 & 1 & 40 & 240 \\
\hline P12 & 6 & 1 & 55 & 330 \\
\hline \multicolumn{4}{|c|}{ TOTAL } & 1338 \\
\hline \multicolumn{4}{|c|}{ TOTAL Bkp } & 20769 \\
\hline
\end{tabular}

Berikut adalah perhitungan beban kerja jam orang per pegawai dalam sehari:

1) Perhitungan Jam Orang (JO) Per Hari Depo

$$
\begin{aligned}
\text { Beban Kerja Per Bulan } & =\text { Bkp }: 12 \\
& =20769: 12 \\
& =1730,75 \text { Jam Orang }
\end{aligned}
$$

JO Per Hari $\quad=$ Beban kerja per bulan

Jumlah hari kerja per bulan

$=1730,75: 26$

= 67 Jam Orang

2) Perhitungan Jam Orang (JO) Per Hari Per Orang JO Per Orang

$$
\begin{aligned}
& =\text { JO Per Hari }: \text { Banyak Pegawai } \\
& =67: 19 \\
& =4 \text { Jam Orang }
\end{aligned}
$$


Dari hasil analisis di atas didapatkan hasil perhitungan beban kerja jam orang per pegawai dalam sehari adalah 4 jam perhari, sedangkan jam kerja rutin dalam sehari pegawai adalah 6 jam. Jadi pegawai dapat menambah jumlah sarana yang akan dirawat atau bekerja lebih detail sehingga menghasilkan hasil yang maksimal. Berdasarkan Keputusan Direksi PT.KAI (PERSERO) Nomor KEP.U/KP.101/I/10/KA-2014 tentang Metode Perhitungan Beban Kerja Dan Kebutuhan Pekerja Di Lingkungan PT.KAI (PERSERO), disebutkan bahwa metode yang digunakan dalam perhitungan kebutuhan pegawai perawatan adalah:

$$
\text { Pegawai Pegawai Perawatan = }(\mathrm{Bkp} / \mathrm{Jkp}) \times \text { In pegawai }
$$

Sesuai perhitungan berdasarkan metode yang digunakan oleh PT.KAI, maka didapatkan kebutuhan pegawai perawatan seharusnya adalah 11 pegawai sedangkan jumlah pegawai perawatan saat ini adalah 19 pegawai. Jadi untuk pegawai perawatan masih surplus 8 pegawai. Jumlah pegawai tersebut berbanding terbalik dengan yang ada di PUS Kediri sehingga perawatan harus dilakukan di Depo Kereta Madiun. Namun pada realisasinya pegawai Depo Kereta Madiun baru dapat melaksanakan perawatan pada pukul 10.00 pagi karena harus menunggu kiriman kereta yang akan melakukan perawatan dari Stasiun Kediri.

\section{Peralatan Perawatan}

Dalam menentukan peralatan minimum yang harus terdapat di depo kereta, pendekatan yang digunakan adalah berdasarkan Instruksi Kerja Perawatan Depo Kereta dan juga check sheet perawatan depo kereta. Peralatan yang digunakan pada proses perawatan kereta, dapat dilihat pada tabel di bawah ini sesuai dengan kebutuhan pemeriksaan dan perbaikan yang harus dilakukan sebagai pedoman perawatan kereta.

Tabel 2. Peralatan Pada Perawatan Harian

\begin{tabular}{|c|l|l|}
\hline \multicolumn{2}{|c|}{ KEGIATAN } & \multicolumn{1}{|c|}{ PERALATAN YANG DIGUNAKAN } \\
\hline NO & \multicolumn{1}{|c|}{ Temeriksaan Bogie } & Visual, thermometer digital dan Palu \\
\hline 2 & Pemeriksaan Alat Perangkai & Visual ,Alat Ukur Tinggi Buffer, jangka sorong \\
\hline 3 & Pemeriksaan Alat Pengereman & Visual ,manometer, dan jangka sorong \\
\hline 4 & Pemeriksaan Interior dan Exterior & Visual, thermometer, obeng, tang \\
\hline 5 & Pemeriksaan Genset & Visual, tang, obeng, dan tespen \\
\hline
\end{tabular}

Tabel 3. Peralatan Pada Perawatan 1 Bulanan (P1)

\begin{tabular}{|c|c|c|}
\hline $\mathrm{NO}$ & KEGIATAN & PERALATAN YANG DIGUNAKAN \\
\hline 1 & Pemeriksaan Bogie & $\begin{array}{l}\text { Creck Detektor, Visual, Palu, } \\
\text { kunci pas, Kunci Ring, Kunci } \\
\text { Inggris, Kacher, kunci pipa, } \\
\text { selang air }\end{array}$ \\
\hline 2 & Pengukuran Roda & $\begin{array}{l}\text { Wheel base gauge, Wheel diameter gauge, } L- \\
\text { Match,mal profile bandase }\end{array}$ \\
\hline 3 & Pemeriksaan Alat Pengereman & Visual ,manometer, dan jangka sorong \\
\hline 4 & Pemeriksaan Rubber Bellow & Visual \\
\hline 5 & Pemeriksaan Instalasi Listrik & $\begin{array}{l}\text { Visual, tespen, tang ampere, AVO meter, obeng, } \\
\text { tang }\end{array}$ \\
\hline 6 & Pemeriksaan Instalasi AC & $\begin{array}{l}\text { Visual, tespen, tang ampere, AVO meter, obeng, } \\
\text { tang }\end{array}$ \\
\hline 7 & Pemeriksaan Instalasi Audio Video & Audio Visual \\
\hline 8 & Pemeriksaan Instalasi Pintu Otomatis & Visual, tang, obeng \\
\hline 9 & Pemeriksaan Instalasi Pompa Air & Tang, obeng \\
\hline
\end{tabular}

Tabel 4. Peralatan Pada Perawatan 3 Bulanan (P3)

\begin{tabular}{|c|l|l|}
\hline NO & \multicolumn{1}{|c|}{ KEGIATAN } & \multicolumn{1}{|c|}{ PERALATAN YANG DIGUNAKAN } \\
\hline 1 & Angkat Body & kunci inggris, crane, pengait \\
\hline 2 & Ukur ketebalan center plate liner & Mistar \\
\hline 3 & Pengukuran Roda & $\begin{array}{l}\text { Wheel base gauge, } \text { Wheel diameter gauge, } L- \\
\text { Match, mal profile bandase }\end{array}$ \\
\hline
\end{tabular}




\begin{tabular}{|c|l|l|}
\hline 4 & Pemeriksaan Bogie & $\begin{array}{l}\text { Creck Detektor, mesin las, Visual, Kacher, } \\
\text { penyemprot solar dan oli, kunci pipa selang air, } \\
\text { dan palu }\end{array}$ \\
\hline 5 & Pemeriksaan Alat Perangkai & Visual,Alat Ukur Tinggi Buffer, jangka sorong \\
\hline 6 & Pemeriksaan Alat Pengereman & Visual ,manometer, dan jangka sorong \\
\hline 7 & Pemeriksaan Exterior dan interior & Visual, thermometer, obeng, tang \\
\hline
\end{tabular}

Tabel 5. Lanjutan

\begin{tabular}{|c|l|l|}
\hline NO & \multicolumn{1}{|c|}{ KEGIATAN } & \multicolumn{1}{|c|}{ PERALATAN YANG DIGUNAKAN } \\
\hline 8 & Ukur clearence side bearer & Alat ukur clearance \\
\hline 9 & Pemeriksaan Instalasi Listrik & $\begin{array}{l}\text { Visual, tespen, tang ampere, AVO meter, obeng, } \\
\text { tang }\end{array}$ \\
\hline 10 & Pemeriksaan Instalasi AC & $\begin{array}{l}\text { Visual, tespen, tang ampere, AVO meter, obeng, } \\
\text { tang }\end{array}$ \\
\hline 11 & Pemeriksaan Instalasi Audio Video & Visual, obeng \\
\hline 12 & Pemeriksaan Instalasi Pintu Otomatis & Visual \\
\hline 13 & Pemeriksaan Instalasi Pompa Air & Tang, obeng \\
\hline 14 & Tes AC & Thermometer \\
\hline
\end{tabular}

Tabel 6. Peralatan Pada Perawatan 6 Bulanan (P6)

\begin{tabular}{|c|l|l|}
\hline NO & \multicolumn{1}{|c|}{ KEGIATAN } & \multicolumn{1}{|c|}{ PERALATAN YANG DIGUNAKAN } \\
\hline 1 & Angkat Body & $\begin{array}{l}\text { Lifting jack, palu, tang,Kunci pas, Kunci Ring, } \\
\text { kunci inggris, crane, pengait }\end{array}$ \\
\hline 2 & Ukur ketebalan center plate liner & Mistar \\
\hline 3 & Pengukuran Roda & $\begin{array}{l}\text { Wheel base gauge, Wheel diameter gauge, L- } \\
\text { Match, mal profile bandase }\end{array}$ \\
\hline 4 & Pemeriksaan Bogie & $\begin{array}{l}\text { Creck detector, mesin las, Visual, Kacher, } \\
\text { penyemprot solar dan oli, kunci pipa, selang air, } \\
\text { dan palu }\end{array}$ \\
\hline 5 & Pemeriksaan Alat Perangkai & Visual, Alat Ukur Tinggi Buffer, jangka sorong \\
\hline 6 & Pemeriksaan Alat Pengereman & Visual ,manometer, dan jangka sorong \\
\hline 7 & Pemeriksaan Exterior dan interior & Visual, thermometer, obeng, tang \\
\hline 8 & Ukur clearence side bearer & Alat ukur clearance \\
\hline 9 & Pemeriksaan Instalasi Listrik & $\begin{array}{l}\text { Visual, tespen, tang ampere, AVO meter, obeng, } \\
\text { tang }\end{array}$ \\
\hline 10 & Pemeriksaan Instalasi AC & $\begin{array}{l}\text { Visual, tespen, tang ampere, AVO meter, obeng, } \\
\text { tang }\end{array}$ \\
\hline 11 & Pemeriksaan Instalasi Audio Video & Audio Visual \\
\hline 12 & $\begin{array}{l}\text { Pemeriksaan Instalasi Pintu } \\
\text { Otomatis }\end{array}$ & Visual \\
\hline 13 & Pemeriksaan Instalasi Pompa Air & Tang, obeng \\
\hline 14 & Tes AC & Thermometer \\
\hline
\end{tabular}

Tabel 7. Peralatan Pada Perawatan 12 Bulanan (P12)

\begin{tabular}{|c|l|l|}
\hline NO & \multicolumn{1}{|c|}{ KEGIATAN } & \multicolumn{1}{|c|}{ PERALATAN YANG DIGUNAKAN } \\
\hline 1 & Angkat Body & $\begin{array}{l}\text { Lifting jack, palu, tang, Kunci pas, Kunci Ring, } \\
\text { kunci inggris, crane, pengait }\end{array}$ \\
\hline 2 & Ukur ketebalan center plate liner & Mistar \\
\hline 3 & Pengukuran Roda & $\begin{array}{l}\text { Wheel base gauge, } \text { Wheel diameter gauge, L- } \\
\text { Match, mal profile bandase }\end{array}$ \\
\hline 4 & Pemeriksaan Bogie & $\begin{array}{l}\text { Visual, mesin las, Kacher, penyemprot solar dan } \\
\text { oli, kunci pipa, selang air, dan palu }\end{array}$ \\
\hline 5 & Pemeriksaan Alat Perangkai & Visual, Alat Ukur Tinggi Buffer, jangka sorong \\
\hline 6 & Pemeriksaan Alat Pengereman & Visual , manometer, dan jangka sorong \\
\hline 7 & Pemeriksaan Exterior dan interior & Visual, thermometer, obeng, tang \\
\hline 8 & Ukur clearence side bearer & Alat ukur clearance \\
\hline 9 & Pemeriksaan Instalasi Listrik & $\begin{array}{l}\text { Visual, tespen, tang ampere, AVO meter, obeng, } \\
\text { tang }\end{array}$ \\
\hline 10 & Pemeriksaan Instalasi AC & $\begin{array}{l}\text { Visual, tespen, tang ampere, AVO meter, obeng, } \\
\text { tang }\end{array}$ \\
\hline 11 & Pemeriksaan Instalasi Audio Video & Audio Visual, obeng \\
\hline
\end{tabular}




\begin{tabular}{|c|l|l|}
\hline 12 & $\begin{array}{l}\text { Pemeriksaan Instalasi Pintu } \\
\text { Otomatis }\end{array}$ & Visual \\
\hline 13 & Pemeriksaan Instalasi Pompa Air & Tang, obeng \\
\hline 14 & Tes AC & Thermometer \\
\hline
\end{tabular}

Tabel 8. Peralatan Pada Perawatan Genset 300 Jam Dan 600 Jam

\begin{tabular}{|l|l|l|}
\hline NO & \multicolumn{1}{|c|}{ KEGIATAN } & \multicolumn{1}{|c|}{ PERALATAN YANG DIGUNAKAN } \\
\hline 1 & Periksa Sistem ahan Bakar & $\begin{array}{l}\text { Visual,Kunci pas, kunci Ring, kuas/majun, } \\
\text { kunci pipa }\end{array}$ \\
\hline 2 & Periksa Sistem Pelumasan & Visual, deepstick \\
\hline 3 & Periksa Sistem Pendinginan & Visual, kuas/majun \\
\hline 4 & Pemeriksaan Filter Udara & Visual, tang, kuas/majun \\
\hline 5 & Pemeriksaan V-Belt & Visual, kunci pas, Kunci Ring \\
\hline 6 & Pemeriksaan Alternator & Visual, tang, obeng \\
\hline 7 & Pemeriksaan Battery & Visual, obeng, tang \\
\hline 8 & Pemeriksaan Baut & Kunci pas, kunci ring, kunci ring, tang \\
\hline 9 & Pemeriksaan Kelistrikan & $\begin{array}{l}\text { Visual, tespen, tang ampere, AVO meter, } \\
\text { obeng, tang }\end{array}$ \\
\hline 10 & Pemeriksaan Ruang Genset & Kacher, majun, selang air \\
\hline 11 & Pemeriksaan Rangka Bawah & Kacher \\
\hline
\end{tabular}

Tabel 9. Peralatan Pada Perawatan Genset 1200 Jam Dan 2400 Jam

\begin{tabular}{|c|l|l|}
\hline NO & \multicolumn{1}{|c|}{ KEGIATAN } & \multicolumn{1}{|c|}{ PERALATAN YANG DIGUNAKAN } \\
\hline 1 & Periksa Sistem Bahan Bakar & $\begin{array}{l}\text { Visual,Kunci pas,kunci ring, kuas/majun, kunci } \\
\text { pipa }\end{array}$ \\
\hline 2 & Periksa Sistem Pelumasan & Visual \\
\hline 3 & Periksa Sistem Pendinginan & Visual, kuas/majun \\
\hline 4 & Pemeriksaan Filter Udara & Visual, tang, kuas/majun \\
\hline 5 & Pemeriksaan V-Belt & Visual, kunci pas, kunci ring \\
\hline 6 & Pemeriksaan Alternator & Visual, tang, obeng \\
\hline 7 & Pemeriksaan Battery & Visual, obeng, tang \\
\hline 8 & Pemeriksaan Baut & Kunci pas, kunci ring, tang \\
\hline 9 & Pemeriksaan Kelistrikan & $\begin{array}{l}\text { Visual, tespen, tang } \text { ampere, AVO meter, obeng, } \\
\text { tang }\end{array}$ \\
\hline 10 & Pemeriksaan Ruang Genset & Kacher, majun \\
\hline 11 & Pemeriksaan Rangka Bawah & Kacher \\
\hline 12 & Pemeriksaan Nozel & Visual, obeng, tang, nozzle tester \\
\hline 13 & Pemeriksaan Intercooler & $\begin{array}{l}\text { kuas/majun, kompresor } \\
\text { tang }\end{array}$ \\
\hline 14 & Pemeriksaan Alat pengaman Motor Diesel tang ampere, AVO meter, obeng, \\
\hline
\end{tabular}

Tabel 10. Peralatan Pada Perawatan Genset 1800 Jam Dan 3600 Jam

\begin{tabular}{|c|l|l|}
\hline NO & \multicolumn{1}{|c|}{ KEGIATAN } & \multicolumn{1}{|c|}{ PERALATAN YANG DIGUNAKAN } \\
\hline 1 & Periksa Sistem Bahan Bakar & $\begin{array}{l}\text { Visual,Kunci pas, kunci ring,kuas/majun, kunci } \\
\text { pipa }\end{array}$ \\
\hline 2 & Periksa Sistem Pelumasan & Visual \\
\hline 3 & Periksa Sistem Pendinginan & Visual, kuas/majun \\
\hline 4 & Pemeriksaan Filter Udara & Visual, tang, kuas/majun \\
\hline 5 & Pemeriksaan V-Belt & Visual, kunci pas, kunci ring \\
\hline 6 & Pemeriksaan Alternator & Visual, tang, obeng \\
\hline 7 & Pemeriksaan Battery & Visual, obeng, tang \\
\hline 8 & Pemeriksaan Baut & Kunci pas, kunci ring, tang \\
\hline 9 & Pemeriksaan Kelistrikan & $\begin{array}{l}\text { Visual, tespen, tang ampere, AVO meter, obeng, } \\
\text { tang }\end{array}$ \\
\hline 10 & Pemeriksaan Ruang Genset & Kacher, majun \\
\hline 11 & Pemeriksaan Rangka Bawah & Kacher \\
\hline 12 & Pemeriksaan Nozel & Visual, obeng, tang, nozzle tester \\
\hline 13 & Pemeriksaan Intercooler & kuas/majun, kompresor \\
\hline
\end{tabular}




\begin{tabular}{|l|l|l|}
\hline 14 & Pemeriksaan Alat pengaman Motor Diesel & $\begin{array}{l}\text { Visual, tespen, tang ampere, AVO meter, obeng, } \\
\text { tang }\end{array}$ \\
\hline 15 & Pemeriksaan Klep & Visual, tang, obeng \\
\hline 16 & Pemeriksaan Starter Motor & Visual, tang, kuas \\
\hline 17 & Pemeriksaan Turbo Charger & Visual, tang, kuas \\
\hline 18 & Pemeriksaan Pompa Oli & Visual \\
\hline 19 & Pemeriksaan Relly Valve & Visual, kuas \\
\hline 20 & Walter Pump & Visual, kuas \\
\hline
\end{tabular}

Berdasarkan hasil analisis terhadap Instruksi Kerja perawatan di Depo Kereta Madiun, maka perbandingan kebutuhan peralatan terhadap ketersediaan peralatan di depo kereta adalah seperti yang tertera pada tabel berikut ini :

Tabel 11. Perbandingan Kebutuhan Peralatan Terhadap Ketersediaan Peralatan Depo Kereta Madiun dan PUS Kediri

\begin{tabular}{|c|c|c|c|c|c|c|c|c|c|}
\hline \multirow[b]{2}{*}{ NO } & \multirow[b]{2}{*}{ Jenis Pemeliharaan } & \multicolumn{6}{|c|}{ Jenis Perawatan } & \multirow[b]{2}{*}{$\begin{array}{l}\text { Ketersediaan di } \\
\text { Depo Madiun }\end{array}$} & \multirow[b]{2}{*}{$\begin{array}{l}\text { Ketersediaan di } \\
\text { PUS Kediri }\end{array}$} \\
\hline & & Harian & $\mathrm{P} 1$ & $\begin{array}{l}\mathrm{P} \\
3\end{array}$ & $\begin{array}{l}P \\
6\end{array}$ & $\begin{array}{l}\mathrm{P} \\
12\end{array}$ & $\begin{array}{l}\text { Gen } \\
\text { set }\end{array}$ & & \\
\hline 1 & Lifting jack & & & $\sqrt{ }$ & $\sqrt{ }$ & $\sqrt{ }$ & & $\sqrt{ }$ & \\
\hline 2 & $\begin{array}{l}\text { Pengait Untuk Angkat } \\
\text { Bogie }\end{array}$ & & & $\sqrt{ }$ & $\sqrt{ }$ & $\sqrt{ }$ & & $\sqrt{ }$ & \\
\hline 3 & Crane & & & $\sqrt{ }$ & $\sqrt{ }$ & $\sqrt{ }$ & & & \\
\hline 4 & Jalur Kolong & & & $\sqrt{ }$ & $\sqrt{ }$ & $\sqrt{ }$ & & $\sqrt{ }$ & $\sqrt{ }$ \\
\hline 5 & $\begin{array}{l}\text { Wheel base gauge } \\
\text { (alat ukur jarak as } \\
\text { roda) }\end{array}$ & & $\sqrt{ }$ & $\sqrt{ }$ & $\sqrt{ }$ & $\sqrt{ }$ & & $\sqrt{ }$ & \\
\hline 6 & $\begin{array}{l}\text { Wheel diameter gauge } \\
\text { (alat ukur diameter } \\
\text { roda) }\end{array}$ & & $\sqrt{ }$ & $\sqrt{ }$ & $\sqrt{ }$ & $\sqrt{ }$ & & $\sqrt{ }$ & \\
\hline 7 & $\begin{array}{l}\text { L-Match (alat ukur } \\
\text { tebal kasut roda) }\end{array}$ & & $\sqrt{ }$ & $\sqrt{ }$ & $\sqrt{ }$ & $\sqrt{ }$ & & $\sqrt{ }$ & \\
\hline 8 & $\begin{array}{l}\text { Mal profile bandase } \\
\text { (alat ukur keausan } \\
\text { flens roda) }\end{array}$ & & $\sqrt{ }$ & $\sqrt{ }$ & $\sqrt{ }$ & $\sqrt{ }$ & & $\sqrt{ }$ & \\
\hline 9 & $\begin{array}{l}\text { Manometer (alat ukur } \\
\text { tekanan angin) }\end{array}$ & $\sqrt{ }$ & $\sqrt{ }$ & $\sqrt{ }$ & $\sqrt{ }$ & $\sqrt{ }$ & & $\sqrt{ }$ & $\sqrt{ }$ \\
\hline 10 & $\begin{array}{l}\text { Alat Ukur Tinggi } \\
\text { Buffer }\end{array}$ & $\sqrt{ }$ & & $\sqrt{ }$ & $\sqrt{ }$ & $\sqrt{ }$ & & & \\
\hline 11 & $\begin{array}{l}\text { Alat Ukur Clearance } \\
\text { (alat ukur clearanc } \\
\text { side bearer dengan } \\
\text { body) }\end{array}$ & & & $\sqrt{ }$ & $\sqrt{ }$ & $\sqrt{ }$ & & & \\
\hline 12 & $\begin{array}{l}\text { Creck Detektor (alat } \\
\text { uji keretakan) }\end{array}$ & & $\sqrt{ }$ & $\sqrt{ }$ & $\sqrt{ }$ & $\sqrt{ }$ & & & \\
\hline 13 & $\begin{array}{l}\text { Kacher (penyemprot } \\
\text { air) }\end{array}$ & & $\sqrt{ }$ & $\sqrt{ }$ & $\sqrt{ }$ & $\sqrt{ }$ & $\sqrt{ }$ & $\sqrt{ }$ & $\sqrt{ }$ \\
\hline 14 & $\begin{array}{l}\text { Penyemprot Oli Dan } \\
\text { Solar }\end{array}$ & & & $\sqrt{ }$ & $\sqrt{ }$ & $\sqrt{ }$ & & & \\
\hline
\end{tabular}

Tabel 12. Lanjutan

\begin{tabular}{|c|c|c|c|c|c|c|c|c|c|}
\hline \multirow{2}{*}{ NO } & \multirow[b]{2}{*}{ Jenis Pemeliharaan } & \multicolumn{6}{|c|}{ Jenis Perawatan } & \multirow[b]{2}{*}{$\begin{array}{l}\text { Ketersediaan di } \\
\text { Depo Madiun }\end{array}$} & \multirow[b]{2}{*}{$\begin{array}{l}\text { Ketersediaan di } \\
\text { PUS Kediri }\end{array}$} \\
\hline & & Harian & $\mathrm{P} 1$ & $\begin{array}{l}\mathrm{P} \\
3\end{array}$ & $\begin{array}{l}\mathrm{P} \\
6\end{array}$ & $\begin{array}{c}\mathrm{P} \\
12\end{array}$ & $\begin{array}{c}\text { Gen } \\
\text { set }\end{array}$ & & \\
\hline 16 & $\begin{array}{l}\text { Deep Stick (alat ukur } \\
\text { volume oli) }\end{array}$ & & & & & & $\sqrt{ }$ & $\sqrt{ }$ & \\
\hline 17 & Nozzle Tester & & & & & & $\sqrt{ }$ & & \\
\hline 18 & Kompresor & & & & & & $\sqrt{ }$ & $\sqrt{ }$ & $\sqrt{ }$ \\
\hline 19 & Thermometer Digital & $\sqrt{ }$ & $\sqrt{ }$ & $\sqrt{ }$ & $\sqrt{ }$ & $\sqrt{ }$ & & $\sqrt{ }$ & $\sqrt{ }$ \\
\hline 20 & Mesin Las & & & $\sqrt{ }$ & $\sqrt{ }$ & $\sqrt{ }$ & & $\sqrt{ }$ & \\
\hline 21 & Topeng Las & & & $\sqrt{ }$ & $\sqrt{ }$ & $\sqrt{ }$ & & $\sqrt{ }$ & \\
\hline
\end{tabular}




\begin{tabular}{|c|c|c|c|c|c|c|c|c|c|}
\hline 22 & Baju Las & & & $\sqrt{ }$ & $\sqrt{ }$ & $\sqrt{ }$ & & $\sqrt{ }$ & \\
\hline 23 & Betel & & & $\sqrt{ }$ & $\sqrt{ }$ & $\sqrt{ }$ & & $\sqrt{ }$ & \\
\hline 24 & Sikat Baja & & & $\sqrt{ }$ & $\sqrt{ }$ & $\sqrt{ }$ & & $\sqrt{ }$ & $\sqrt{ }$ \\
\hline 25 & Sekrap & & & $\sqrt{ }$ & $\sqrt{ }$ & $\sqrt{ }$ & & $\sqrt{ }$ & $\sqrt{ }$ \\
\hline 26 & Kunci Inggris & & $\sqrt{ }$ & $\sqrt{ }$ & $\sqrt{ }$ & $\sqrt{ }$ & & $\sqrt{ }$ & $\sqrt{ }$ \\
\hline 27 & Kunci Pas & & $\sqrt{ }$ & $\sqrt{ }$ & $\sqrt{ }$ & $\sqrt{ }$ & $\sqrt{ }$ & $\sqrt{ }$ & $\sqrt{ }$ \\
\hline 28 & Kunci Ring & & $\sqrt{ }$ & $\sqrt{ }$ & $\sqrt{ }$ & $\sqrt{ }$ & $\sqrt{ }$ & $\sqrt{ }$ & $\sqrt{ }$ \\
\hline 29 & Kunci Pipa & & $\sqrt{ }$ & $\sqrt{ }$ & $\sqrt{ }$ & $\sqrt{ }$ & $\sqrt{ }$ & $\sqrt{ }$ & $\sqrt{ }$ \\
\hline 30 & Obeng & $\sqrt{ }$ & $\sqrt{ }$ & $\sqrt{ }$ & $\sqrt{ }$ & $\sqrt{ }$ & $\sqrt{ }$ & $\sqrt{ }$ & $\sqrt{ }$ \\
\hline 31 & Tang Kombinasi & $\sqrt{ }$ & $\sqrt{ }$ & $\sqrt{ }$ & $\sqrt{ }$ & $\sqrt{ }$ & $\sqrt{ }$ & $\sqrt{ }$ & $\sqrt{ }$ \\
\hline 32 & Palu & $\sqrt{ }$ & $\sqrt{ }$ & $\sqrt{ }$ & $\sqrt{ }$ & $\sqrt{ }$ & & $\sqrt{ }$ & $\sqrt{ }$ \\
\hline 33 & $\begin{array}{l}\text { Jangka Sorong/ } \\
\text { Sketmat }\end{array}$ & $\sqrt{ }$ & $\sqrt{ }$ & $\sqrt{ }$ & $\sqrt{ }$ & $\sqrt{ }$ & & $\sqrt{ }$ & $\sqrt{ }$ \\
\hline 34 & Tang Ampere & & $\sqrt{ }$ & $\sqrt{ }$ & $\sqrt{ }$ & $\sqrt{ }$ & $\sqrt{ }$ & $\sqrt{ }$ & $\sqrt{ }$ \\
\hline 35 & AVO meter & & $\sqrt{ }$ & $\sqrt{ }$ & $\sqrt{ }$ & $\sqrt{ }$ & $\sqrt{ }$ & $\sqrt{ }$ & $\sqrt{ }$ \\
\hline 36 & Tespen & $\sqrt{ }$ & $\sqrt{ }$ & $\sqrt{ }$ & $\sqrt{ }$ & $\sqrt{ }$ & $\sqrt{ }$ & $\sqrt{ }$ & $\sqrt{ }$ \\
\hline 37 & Mistar & & & $\sqrt{ }$ & $\sqrt{ }$ & $\sqrt{ }$ & & $\sqrt{ }$ & $\sqrt{ }$ \\
\hline 38 & Kuas/Majun & & & & & & $\sqrt{ }$ & $\sqrt{ }$ & $\sqrt{ }$ \\
\hline 39 & Stop Blok & & $\sqrt{ }$ & $\sqrt{ }$ & $\sqrt{ }$ & $\sqrt{ }$ & & $\sqrt{ }$ & $\sqrt{ }$ \\
\hline 40 & Roll Meter & & & $\sqrt{ }$ & $\sqrt{ }$ & $\sqrt{ }$ & & $\sqrt{ }$ & $\sqrt{ }$ \\
\hline
\end{tabular}

Tabel 13. Lanjutan

\begin{tabular}{|c|c|c|c|c|c|c|c|c|c|}
\hline \multirow[b]{2}{*}{ NO } & \multirow[b]{2}{*}{ Jenis Pemeliharaan } & \multicolumn{6}{|c|}{ Jenis Perawatan } & \multirow[b]{2}{*}{$\begin{array}{l}\text { Ketersediaan di } \\
\text { Depo Madiun }\end{array}$} & \multirow[b]{2}{*}{$\begin{array}{l}\text { Ketersediaan di } \\
\text { PUS Kediri }\end{array}$} \\
\hline & & Harian & $\mathrm{P} 1$ & $\begin{array}{l}\mathrm{P} \\
3\end{array}$ & $\begin{array}{l}\mathrm{P} \\
6\end{array}$ & $\begin{array}{c}\mathrm{P} \\
12\end{array}$ & $\begin{array}{l}\text { Gen } \\
\text { set }\end{array}$ & & \\
\hline 41 & $\begin{array}{l}\text { Balok } \\
(600 \times 250 \times 200 \mathrm{~mm})\end{array}$ & & & $\sqrt{ }$ & $\sqrt{ }$ & $\sqrt{ }$ & & $\sqrt{ }$ & $\sqrt{ }$ \\
\hline 42 & Helm & $\sqrt{ }$ & $\sqrt{ }$ & $\sqrt{ }$ & $\sqrt{ }$ & $\sqrt{ }$ & $\sqrt{ }$ & $\sqrt{ }$ & $\sqrt{ }$ \\
\hline 43 & Wear Pack & $\sqrt{ }$ & $\sqrt{ }$ & $\sqrt{ }$ & $\sqrt{ }$ & $\sqrt{ }$ & $\sqrt{ }$ & $\sqrt{ }$ & $\sqrt{ }$ \\
\hline 44 & Sarung Tangan & $\sqrt{ }$ & $\sqrt{ }$ & $\sqrt{ }$ & $\sqrt{ }$ & $\sqrt{ }$ & $\sqrt{ }$ & $\sqrt{ }$ & $\sqrt{ }$ \\
\hline 45 & Sepatu Pengaman & $\sqrt{ }$ & $\sqrt{ }$ & $\sqrt{ }$ & $\sqrt{ }$ & $\sqrt{ }$ & $\sqrt{ }$ & $\sqrt{ }$ & $\sqrt{ }$ \\
\hline
\end{tabular}

Dari hasil analisis terhadap kelengkapan peralatan perawatan di Depo Kereta Madiun, menunjukan bahwa dari seluruh standar peralatan kerja yang harus dimiliki depo kereta ada beberapa peralatan yang belum dimiliki oleh Depo Kereta Madiun, yaitu Crane, alat ukur tinggi buffer, alat ukur clearance side bearer dengan body, creck detector, dan penyemprot oli dan solar. Ketidaktersediannya alat tersebut dapat menimbulkan dampak, misalnya akibat dari tidak ada peralatan pengukur tinggi buffer dari kepala rel yang melebihi batas maksimal $785 \mathrm{~mm}$ dan batas tinggi buffer terendah adalah $680 \mathrm{~mm}$, apabila tidak segera di perbaiki dapat menyebabkan sambungan antar kereta terlepas. 
Dampak dari ketidakadaan alat ukur clearance pada side bearer yaitu clearance antara side bearer dengan pivot tidak terpantau, apabila selisihnya lebih dari $4 \mathrm{~mm}$ maka dapat terjadi tekanan body kereta pada side bearer yang dapat mengggangu pemegasan kereta. Solusi yang telah dilakukan saat ini yaitu dangan menggunakan alat ukur meteran dan papan datar untuk menggantikan alat ukur ketinggian buffer, mengukur clearance side bearer dengan mistar, mengganti alat penyemprot solar dengan dengan mengoleskan solar dengan kain yang dibasahi solar, dan lain-lain.

Namun solusi mengganti peralatan tersebut dikhawatiran tingkat keakuratannya, sehingga diperlukan pemantauan lebih terhadap peralatan- peralatan tersebut. Apabila perawatan kereta akan dipindahkan ke PUS Kediri, maka PUS Kediri harus melengkapi peralatan standar untuk perawatan seperti Pengait Untuk Angkat Bogie, Crane, Wheel base gauge (alat ukur jarak as roda), Wheel diameter gauge (alat ukur diameter roda), L-Match (alat ukur tebal kasut roda), Mal profile bandase (alat ukur keausan flens roda), Alat Ukur Tinggi Buffer, Alat Ukur Clearance (alat ukur clearanc side bearer dengan body), Creck Detektor, dan sebagainya.

\section{Analisis Perbandingan Lokasi Usulan}

Lokasi usulan yang dimaksud dalam penelitian ini adalah lokasi yang akan digunakan sebagai tempat dibentuknya Depo baru di wilayah DAOP 7 Madiun. Analisis ini dilakukan untuk menguji dan mengetahui apakah kelebihan dan kekurangan dengan pemindahan Depo Kereta yang berlokasi di Kediri.

Tabel 14. Perbandingan Lokasi Usulan

\begin{tabular}{|c|c|c|}
\hline & Madiun & Kediri \\
\hline $\begin{array}{c}\text { Kerugian waktu kelambatan } \\
\text { rata-rata PERKA }\end{array}$ & 10 menit & - \\
\hline Waktu pendistribusian & \pm 120 menit & Kediri \pm 10 menit \\
\hline Waktu ganggu di emplasment & $\begin{array}{c}\text { Kediri } \pm 10 \text { menit Madiun } \pm 12 \\
\text { menit }\end{array}$ & Kediri \pm 10 menit \\
\hline Langsiran & $\begin{array}{c}\text { Kediri } \pm 10 \text { menit Madiun } \pm 12 \\
\text { menit }\end{array}$ & $\begin{array}{c}\text { Surplus pegawai dapat } \\
\text { dialihkan kebidang lain }\end{array}$ \\
\hline Pegawai & Surplus 8 pegawai \\
\hline
\end{tabular}

Dari tabel diatas, apabila Depo Induk di Madiun dipindahkan lokasinya ke Kediri. Keutungan yang dapat diperoleh antara lain, kerugian waktu kelambatan rata- rata PERKA dapat diminimalisir, tidak adanya kerugian perjalanan kereta kosong, waktu ganggu diemplasment, dan langsiran hanya terjadi di Kediri serta surplus pagawai dapat dimanfaatkan ke bidang yang lain walaupun harus mengorbankan biaya dalam pemindahan peralatan Depo.

\section{KESIMPULAN}

Berdasarkan hasil analisis yang telah dilakukan, maka dapat diperoleh kesimpulan berupa terjadi kelambatan PERKA akibat manuver dan langsiran di stasiun. Untuk mengurangi kelambatan tersebut pemindahan Depo di Madiun ke Kediri diperlukan. Kemudian fasilitas dan peralatan perawatan di PUS Kediri masih belum mencukupi untuk melakukan perawatan berkala P1, P3, P6, dan P12 dikarenakan belum adanya Lifting Jack, pengait untuk angkat bogie, Crane, Wheel base gauge, Wheel diameter gauge, L-match, Mal Profile Bandase, alat ukur tinggi buffer, Creck detector, Deep stick yang sangat diperlukan. Tidak semuanya lengkap/tidak dimiliki, dan kondisi (sebagian) ada yang rusak Lalu pemindahan depo dari Madiun ke Kediri memiliki kelebihan berupa mengurangi kerugian waktu kelambatan rata- rata PERKA; Waktu distribusi; Mengurangi waktu ganggu di emplasment serta langsiran; dan Menghemat pegawai. 


\section{DAFTAR PUSTAKA}

1. $\mathrm{CH}$, N. O. 2009. Perawatan ketel uap untuk mundukung proses produksi gula dalam usaha mencapai hasil yang efektif pada PG Tasikmadu Karanganyar.

2. Firmansyah, E. 2016. Strategi Rekrutmen dan Seleksi Studi Kasus: PT Kereta Api Indonesia Daerah Operasi 7 Madiun.

3. Kapur, K. C., \& Lamberson, L. R. 1977. Reliability in Engineering Design John Wiley \& Sons. Inc., New York.

4. Kurnia, S. H. 2018. Potensi Kereta Api Sebagai Moda Angkutan Barang Ditinjau Dari Sisi Biaya (Studi Kasus: Tj. Enim Dan Pelabuhan Panjang). Sosialita, 11(1).

5. Perhubungan, D. 2005. Sistem Transportasi Nasional (Sistranas). Peraturan Menteri Perhubungan No: Km. 49 Tahun 2005, 77.

6. Praja, I. I. 2019. Analisis Perawatan Mesin Conveyor Unloading Phosphate Rock Mesir dengan Metode Reliability Centered Maintenance (RCM)(Studi Kasus di PT Petrokimia Gresik) (Doctoral dissertation, Universitas Muhammadiyah Gresik).

7. Pramono, A. 2011. Sejarah Keberadaan Jalur Kereta Api di Kabupaten Wonogiri.

8. Purwono, A., Muhardono, M., \& Ryanto, A. H. 2019. Analysis of Monthly Maintenance Performance (P1, P3, P6) Commuter Line Dipo Depok. Jurnal Perkeretaapian Indonesia (Indonesian Railway Journal), 3(1).

9. Ramadhan, F. F. 2018. Pembangunan Aplikasi Multimedia Sebagai Media Pembelajaran Mesin Diesel Kereta Api (Studi Kasus Di Balai Pusat Pendidikan Dan Pelatihan Pt Kereta Api Indonesia) (Doctoral dissertation, Universitas Komputer Indonesia).

10. Razak, R. 2017. Usulan Perawatan Komponen Pada Unit Off-Highway Truck 793c Dengan Metode RCM (Studi Kasus: PT. Trakindo Utama, Batu Hijau) (Doctoral dissertation, University of Muhammadiyah Malang).

11. Sari, Y. K. 2011. Kinerja PT. KAI (Persero) Daop VI Yogyakarta dalam Pelayanan Gerbong Khusus Wanita Kereta Api Prambanan Ekspres (Studi Kasus pada Stasiun Solo Balapan).

12. Setyabudhi, A. L. 2020. Task Analysis Dalam Kompetensi Perawatan Kendaraan Secara Berkala Di Dunia Industri Otomotif BATAM. Technical and Vocational Education International Journal (TAVEIJ), 1(01), 1-10.

13. Susanto, P. C., Suryawan, R. F., Hartono, H., \& Arief, M. I. 2020. Optimalisasi Kereta Api Airport Railink Services Kualanamu Mendukung Kegiatan Operasional Bandara. Aviasi: Jurnal Ilmiah Kedirgantaraan, 17(2), 54-65.

14. Suwardi, R. I. S., \& Kuswanto, H. 2018. Kebijakan Publik Tentang Sistem Keselamatan Dan Keamanan Perkeretaapian Di Indonesia. Prosiding SNasPPM, 3(1), 282-290.

15. Tazani, A. A., \& Wanto, K. 2020. Analisis Kandungan Minyak Pada Oil Water Separator Di Mt. Ontari. Jurnal Sains Dan Teknologi Maritim, 20(2), 119-131. 